\title{
THE IMPACT OF SELECTED TECHNOLOGICAL AND MATERIAL PARAMETERS ON THE STRENGTH OF ADHESIVE STEEL SHEETS JOINTS
}

\author{
Anna Rudawska', Katarzyna Głogowska', Tatiana Vitenko², \\ Dana Stančeková ${ }^{3}$, Nadežda Čuboňová ${ }^{3}$, Dariusz Kasperek ${ }^{4}$ \\ 1 Lublin University of Technology, Faculty of Mechanical Engineering, Nadbystrzycka 36 Str, 20-618 Lublin, PL, \\ e-mail:a.rudawska@pollub.pl, darek.kasperek@gmail.com \\ 2 Ternopil Ivan Pul'uj National Technical University, Faculty of Mechanical Engineering and Food Technologies, \\ Ruska Street 56, 46001, Ternopil, UK, vitenko@tstu.edu.ua \\ 3 University of Žilina, Faculty of Mechanical Engineering, Univerzitna 1, 010 26, Žilina, SK, dana.stancekova@ \\ fstroj.uniza.sk, nadezda.cubonova@fstroj.uniza.sk \\ ${ }^{4}$ URSUS BUS S.A., ul. Frezerów 7, 20-209 Lublin
}

Received: 2016.11.14

Accepted: 2017.02.07

Published: 2017.06.01

\begin{abstract}
The following paper analyses selected problems regarding the impact of technological parameters and the type of adherend material on the strength of adhesive-bonded steel sheet joints. The subject of the test was a single-lap adhesive joint of S235JR steel sheet. Joints were formed on two types of substrates: with or without corrosion products on the surface. The surface of steel sheet adherends was pre-treated with three cleaning solutions: acetone, Wiko industrial degreasing agent and Cortanin $\mathrm{F}$ anti-corrosion agent, depending on the state of the surface. Adhesive joints were formed with Epidian 53/ET/100:15 epoxy adhesive. The formed joints were subjected to one of three ageing variants: 14 days, two months and 3 months, which were followed by destructive testing to determine the shear strength of joints. The analysis of results obtained in the tests indicates that the strength performance of adhesive joints of corrosion-free adherends was characterised by higher values than in corroded steel sheets, regardless of ageing time.
\end{abstract}

Keywords: adhesive joints, steel sheets, corrosion, ageing, strength, surface treatment.

\section{INTRODUCTION}

Adhesive joining technology covers a broad spectrum of fields, which mainly revolve around the problems of cohesion and adhesion, selection of proper adhesive to given applications, preparation of adherends, preparation and application of adhesive as well as its properties for a given application $[1 \div 5]$.

Obtaining the highest strength of adhesive joints is not be possible without a suitable preparation of the surface of adherends [3, $5 \div 7]$. There is a number of operations that serve as surface preparation methods, such as: degreasing, chemical bath, mechanical and chemical machining, rinsing, drying, applying primers and other spe- cial operations [1, 2, $8 \div 13]$. It is paramount for the strength of joints that surface preparation is carried out with great care. The obtained substrate surface must be contaminant-free of proper structure and the contact between substrates must be close and consistent to ensure the strongest adhesion forces between the adhesive and adherends $[2,7,11]$. Preparation of surface for adhesive joining facilitates producing joint of desired properties. Among factors contributing to decreasing adhesion between adhesive and adherends is corrosion on the surface of substrates $[7,14]$. The term "corrosion" is mainly applied in the context of metal substrates, however, it also concerns non-metallic substrates, such as: concrete, wood, glass or polymers [15]. Corrosion is a phenom- 
a)

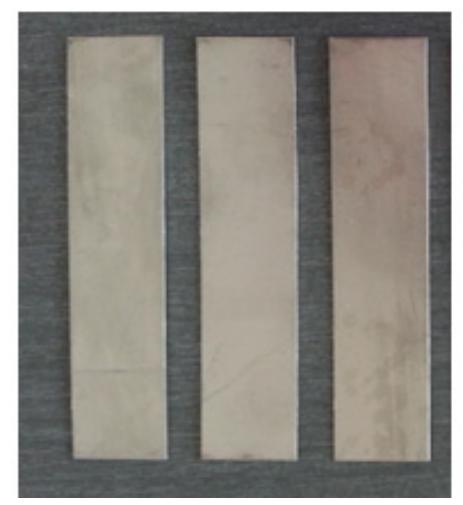

b)

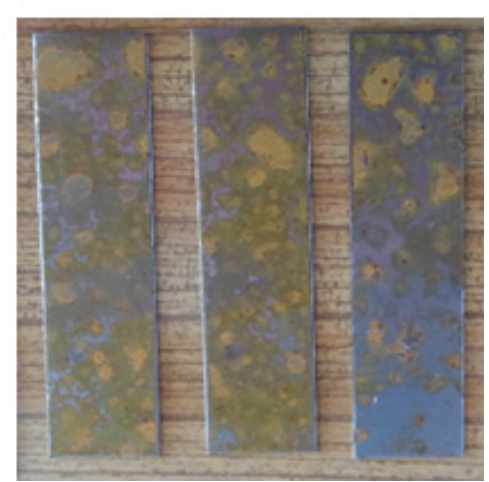

Fig. 1. S235JR steel specimens: a) non-corroded specimen, b) corroded specimen

Table 1. Mechanical properties of S235JR steel [16]

\begin{tabular}{|c|c|c|c|c|}
\hline Property & $\begin{array}{c}\text { Minimum } \\
\text { yield } \\
\text { strength } \\
\mathbf{R}_{\mathrm{e}} \\
\mathbf{M P a}\end{array}$ & $\begin{array}{c}\text { Tensile } \\
\text { strength } \\
\mathbf{R}_{\mathrm{m}} \\
\mathbf{M P a}\end{array}$ & $\begin{array}{c}\text { Minimum } \\
\text { elongation } \\
\mathbf{A}_{\min } \\
\%\end{array}$ & $\begin{array}{c}\text { Notch } \\
\text { impact, } \\
\mathbf{J}\end{array}$ \\
\hline Value & 235 & $360-510$ & 18 & 27 \\
\hline
\end{tabular}

enon which, in its dominant form, consists in degrading metals through chemical or electrochemical reactions with the surrounding environment, which occurs on their interface $[14,15]$.

The present paper analyses selected problems of adhesive joint strength of corroded and corrosion-free steel sheet substrates, which were subjected to different cleaning operations and three time variants of ageing.

\section{TEST METHODOLOGY}

\section{Adherends and adhesive}

The specimens were obtained from non-alloy structural steel sheets S235JR (according to Pol- ish Norm PN-EN 10027-1 [16]). Table 1 shows a selection of steel material mechanical properties. The tests were carried out on S235JR steel specimens with (Fig. 1b) or without corrosion products on the surface (Fig. 1a).

S235JR steel sheet specimens shown in Fig. 1a were characterised by smooth, homogeneous metallic surface with no signs of corrosion. The surface of corroded steel sheet specimens (Fig. 1b) was covered with a considerable amount of corrosion debris, distributed unevenly on the specimen: in certain places, the surface of specimens showed no signs of corrosion. Corrosion on the surface of specimens usually took form of irregular spots of various sizes that were yellow-brown in colour. Corrosion products were strongly bonded with the substrate, however, a certain portion of loosely bonded corroded material could be observed.

\section{Cleaning agents}

Surface treatment consisted in cleaning the surface of adherends with three types of products: acetone, Wiko industrial degreasing agent and Cortanin

Table 2. Physicochemical properties of acetone [17]

\begin{tabular}{|c|c|c|c|c|c|c|}
\hline Property & $\begin{array}{c}\text { Density at } \mathbf{2 0}{ }^{\circ} \mathrm{C}, \\
\mathbf{g} / \mathrm{cm}^{3}\end{array}$ & $\begin{array}{c}\text { Viscosity at } \mathbf{2 0}^{\circ} \mathrm{C}, \\
\mathbf{m P a s}\end{array}$ & $\begin{array}{c}\text { Melting point, } \\
{ }^{\circ} \mathrm{C}\end{array}$ & $\begin{array}{c}\text { Boiling point, } \\
{ }^{\circ} \mathrm{C}\end{array}$ & $\begin{array}{c}\text { Flash point, } \\
{ }^{\circ} \mathrm{C}\end{array}$ & $\begin{array}{c}\text { Auto-ignition temp, } \\
{ }^{\circ} \mathrm{C}\end{array}$ \\
\hline Value & 0.79 & 0.33 & -94.8 & 56.2 & -19 & 540 \\
\hline
\end{tabular}

Table 3. Wiko industrial degreasing agent content [18]

\begin{tabular}{|c|c|c|c|c|c|}
\hline Property & $\begin{array}{c}\text { Petroleum, } \\
\%\end{array}$ & $\begin{array}{c}\text { Acetone, } \\
\%\end{array}$ & $\begin{array}{c}\text { Isobutane, } \\
\%\end{array}$ & $\begin{array}{c}\text { Propane, } \\
\%\end{array}$ & $\begin{array}{c}\text { Carbon dioxide, } \\
\%\end{array}$ \\
\hline Value & $50-100$ & $20-50$ & $1-10$ & $1-10$ & $1-10$ \\
\hline
\end{tabular}


Table 4. Physicochemical properties of Cortanin F anti-corrosion agent [19]

\begin{tabular}{|c|c|c|c|c|c|}
\hline Property & $\begin{array}{c}\text { Density at } \mathbf{2 0}{ }^{\circ} \mathbf{C}, \\
\mathbf{g} / \mathbf{c m}^{3}\end{array}$ & $\begin{array}{c}\text { Solidification } \\
\text { point, }{ }^{\circ} \mathbf{C}\end{array}$ & $\begin{array}{c}\text { Boiling point, } \\
{ }^{\circ} \mathbf{C}\end{array}$ & $\begin{array}{c}\text { Flash point, } \\
{ }^{\circ} \mathbf{C}\end{array}$ & $\mathbf{p H}$ \\
\hline Value & $1.05-1.11$ & -20 & 85 & 32 & $1-2$ \\
\hline
\end{tabular}

F anti-corrosion agent. Tables 2-4 show selected properties features of the products in question.

Acetone $\left(\mathrm{C}_{3} \mathrm{H}_{6} \mathrm{O}\right)$ is a chemical compound belonging to ketone family. Its physicochemical properties, such as low viscosity, water miscibility and the fact that it is also miscible with certain organic solvents makes it a widely applied general purpose solvent. Industrial degreasing agent, Wiko, comes in a form of a highly-concentrated aerosol and is applied in various assembly processes. Cortanin $\mathrm{F}$ anti-corrosion agent is an aqueous alcoholic solution of tannin with an addition of phosphate corrosion inhibitors and surface-active agents. It chemically bonds corrosion products in a stable complex with tannin, which prepares the surface for further operations connected with adhesive bonding.

Degreasing and anti-corrosion agents remove various contamination, oils or metal powder from the surface of substrates. A fundamental property of an anti-corrosion agent is bonding corrosion products that cover the substrate surface. Specimens treated with degreasers and anti-corrosion agents are properly prepared for adhesive bonding, and the joint formed on such surfaces exhibits higher quality.

\section{Adhesive joint design and assembly}

The tests analysed single lap adhesive joints of S235JR steel sheet formed on corroded and corrosion-free substrates, whose shape is shown in Figure 2. The dimensions of joints assembled in the study were: overlap length $l_{z}=16.5 \mathrm{~mm}$, specimen thickness $g=1 \mathrm{~mm}$, joint width $\mathrm{b}=25 \mathrm{~mm}$, adhesive thickness $0.12 \mathrm{~mm}$.

The surface of substrates was cleaned with three types of cleaning agents: acetone, degreasing agent Wiko, and anti-corrosion agent Cortanin F. Corroded specimens were divided into three groups, each subjected to surface pre-treatment with a different cleaning agent. Specimens free of corrosion products were degreased with acetone.

In acetone treatment, acetone was applied on the surface of substrates and then dried. The procedure was repeated three times for each specimen, however, the last coat of acetone was left to dry for 2 minutes. A similar application procedure was followed in cleaning with Wiko degreasing agent,

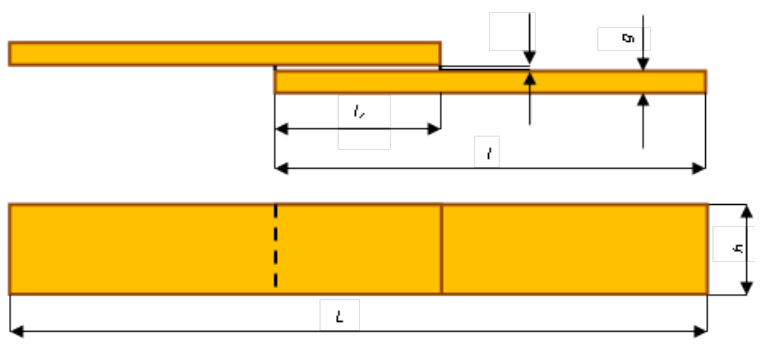

Fig. 2. Steel sheet adhesive joint design

where after the third application the degreaser was left to dry for approximately 5 minutes.

The anti-corrosion agent was applied on the surface of adherends with a brush. Afterwards the samples were left to rest for 24 hours, during which time the anti-corrosion agent could fully bond the products of corrosion covering the surface of steel sheets. After the time required for full activation of the anti-corrosion agent, subsequent operations leading to joint assembly were performed.

Adhesive joints were produced with Epidian 53 epoxy-based adhesive with ET amine curing agent. The desired adhesive composition was obtained by mixing resin and curing agent at a ratio of 100:15 for 2 minutes at ambient temperature of $24-26^{\circ} \mathrm{C}$ and air humidity of approx. $31-32 \%$, until the consistency of the mixture was properly uniform. The adhesive was applied on the pretreated surface of substrates by means of a spatula, so that the thin film of the adhesive was spread evenly and was free of undesired air bubbles. The adhesive was applied on one of the substrates. The application procedure was carried out immediately after blending the adhesive, bearing in mind the pot life of the mixture, whose properties are guaranteed within the specified time. Joints was assembled as soon as the adhesive was applied, bearing in mind the specified lap length. Adhesive joints were assembled at ambient temperature of approx. $24-26^{\circ} \mathrm{C}$ and air humidity of approx. $31-32 \%$. The load of $0.06 \mathrm{MPa}$ was applied to the curing joint for $48 \mathrm{~h}$. The cure time was 7 days. The assembled joints were divided into three groups, each subjected to different ageing time. The three tested ageing variants were: 14 days, 2 months and 3 months (Table 5). 
Table 5. Research variants

\begin{tabular}{|c|c|c|c|c|c|c|}
\hline $\begin{array}{c}\text { Type of } \\
\text { substrate }\end{array}$ & \multicolumn{3}{|c|}{ Non-corroded sheet } & \multicolumn{3}{c|}{ Corroded sheets } \\
\hline \multirow{2}{*}{ Cleaning agent } & \multicolumn{3}{|c|}{ Ageing time } & \multicolumn{3}{c|}{ Ageing time } \\
\cline { 2 - 8 } & 14 days & 2 months & 3 months & 14 days & 2 months & 3 months \\
\hline Acetone & + & + & + & + & + & + \\
\hline Wiko & - & - & - & + & + & + \\
\hline Cortanin F & - & - & - & + & + & + \\
\hline
\end{tabular}

The 12 series of joints, consisting of 8-10 specimens each, were produced according to the considerations shown in Table 5. Upon reaching the subsequent ageing time marks, the joints were subjected to further strength tests. The shear strength of joints was tested on Zwick/Roell Z150 testing machine according to DIN EN 1465 standard [20], at temperature of $21 \pm 1^{\circ} \mathrm{C}$ and humidity $31 \%$. The specified test speed was equal to $5 \mathrm{~mm} / \mathrm{min}$.

\section{TEST RESULTS AND COMPARATIVE ANALYSIS}

\section{Adhesive joints strength - non-corroded substrates}

The comparison of shear strength of noncorroded steel sheet joints cleaned with acetone depending on ageing time is shown in Figure 3.

As shown in Figure 3, the highest joint strength was observed in joints subjected to 2 months of ageing. The average strength amounted to 4.62 MPa, which was higher than in the remaining variants by $1.06 \mathrm{MPa}$ and $1.54 \mathrm{MPa}$. The average strength of non-corroded substrates cleaned

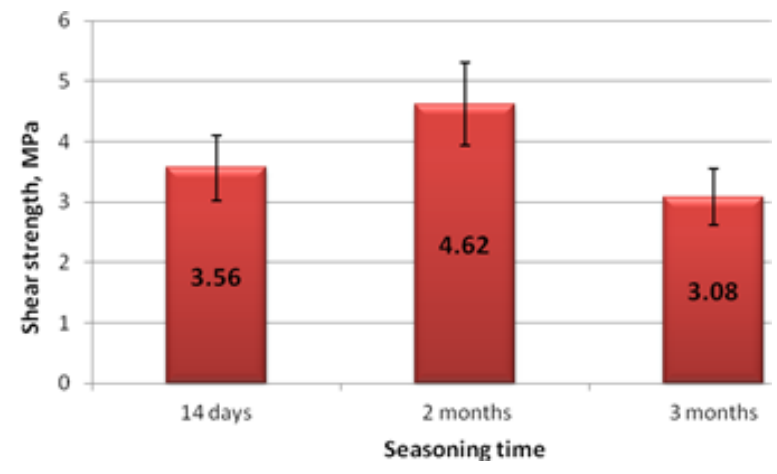

Fig. 3. Adhesive joint strength of non-corroded substrates, cleaned with acetone, depending on ageing time

with acetone after 14 days of ageing amounts to $77 \%$ of maximum obtained strength. The minimum strength of joints subjected to ageing for 3 months was equal to $3.08 \mathrm{MPa}$, corresponding to $67 \%$ of the strength of joints after 2 months.

\section{Adhesive joint strength - corroded substrates - ageing time}

The effect of time of exposure to ageing on the strength of analysed joints of corroded steel sheet substrates depending on the applied cleaning

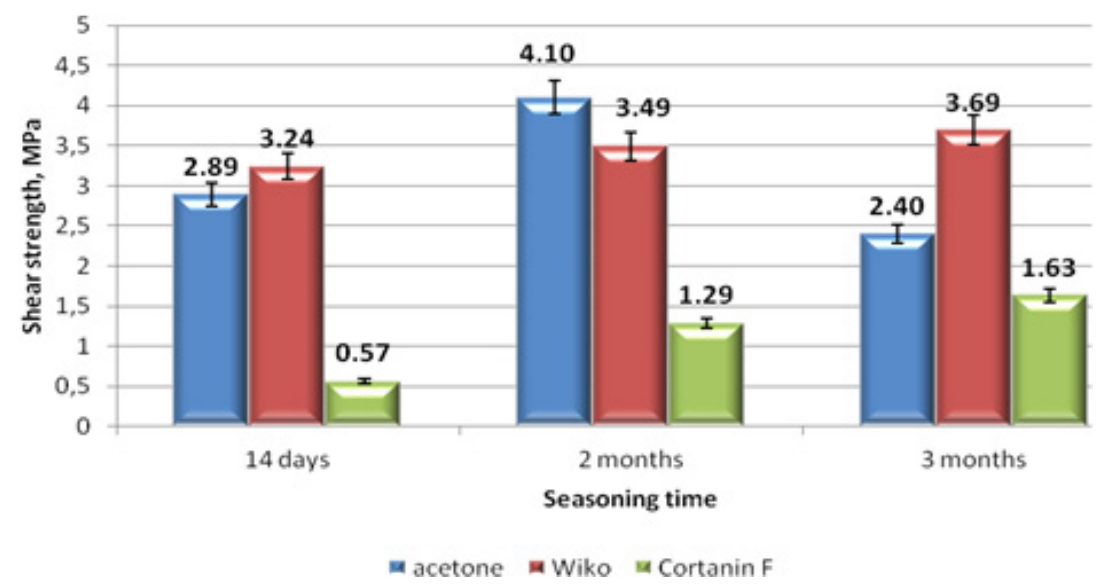

Fig. 4. Effect of surface treatment on adhesive joint strength depending on exposure time 
solution is shown in Figure 4. The analysis of exposure time of 14 days concludes that the highest joint strength in the ageing variant in question was exhibited in specimens where the substrates' surface was pre-treated with Wiko industrial degreasing agent, in which case the strength was equal to 3.24 MPa. Joints of acetone-cleaned substrates exhibited the strength of $2.89 \mathrm{MPa}$, which amounts to $89 \%$ of maximum strength obtained in tests. It was, furthermore, noted that the application of the anti-corrosion agent significantly decreased joint strength, which did not amount to more than 0.57 $\mathrm{MPa}$. Such a low value of shear strength amounts to mere $18 \%$ of the strength observed in specimens pre-treated with Wiko degreaser.

The results obtained for specimens after 2 months of exposure to ageing revealed that the highest strength was obtained in joints subjected to acetone pre-treatment. The average strength value noted for the joint variant in question was equal to $4.10 \mathrm{MPa}$, which was higher than in the case of remaining variants. A further comparison revealed that in joints whose substrates were pretreated with Wiko industrial degreasing agent, the strength obtained after 2-month exposure was still considerable, corresponding to $85 \%$ of the maximum strength. The highest discrepancy in lap shear strength was observed in specimens treated with acetone and anti-corrosion agent, and is equal to $2.81 \mathrm{MPa}$. The strength of $1.29 \mathrm{MPa}$ amounts to mere $30 \%$ of maximum strength. In joints exposed to ageing for 3 months it was observed that lap shear strength values for different surface treatment agents showed significant differences. Joints cleaned with Wiko degreasing agent produced strength on a high level of 3.69 $\mathrm{MPa}$, which exceeds the joint strength measured for the remaining two surface treatment variants. Acetone-treated substrates formed joints whose strength amounted to $65 \%$ of maximum strength, whereas the lowest lap shear strength was observed in specimens subjected to treatment by means of the anti-corrosion agent, in which case it was equal to $1.63 \mathrm{MPa}$, i.e. $44 \%$ of maximum strength of joints cleaned with Wiko degreaser.

\section{Adhesive joint strength - corroded substrates - surface pre-treatment}

The effect of surface treatment on joint strength of corroded steel sheet substrates depending on time of exposure to ageing is shown in Fig. 5. As shown in Fig. 5, the highest strength was obtained in adhesive-bonded joints of corroded substrates that were prepared for bonding through cleaning with acetone and subjected to ageing for two months. The strength in those joints amounted to $4.10 \mathrm{MPa}$, and constituted the highest noted among the tested ageing variants. The exposure times of 14 days and 3 months produced joints whose strength corresponded to respectively $70 \%$ and $58 \%$ of the lap shear strength exhibited by joints after 2-month exposure time. Furthermore, it was observed that the strength of joints of corroded substrates that were subjected to pretreatment with Wiko industrial degreasing agent was rather consistent in all ageing variants. The highest joint strength was obtained after 3-month exposure time, $3.69 \mathrm{MPa}$. In the remaining cases, i.e. the exposure of 14 days and 2 months, the obtained joint strength amounted to $3.24 \mathrm{MPa}$ and $3.49 \mathrm{MPa}$ respectively, which is equal to $88 \%$ and $95 \%$ of the maximum obtained strength. The scatter of results is considerably low, which indi-

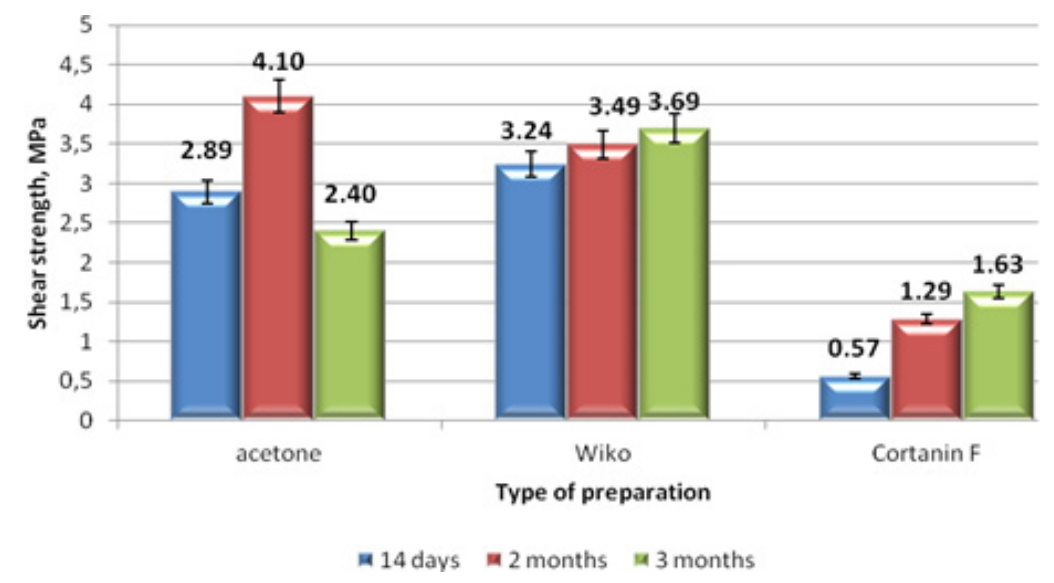

Fig. 5. Effect of exposure time on adhesive joint strength depending on surface treatment 
cates high repeatability of strength values exhibited by adhesive-bonded specimens which were pre-treated with Wiko degreaser. The strength of joints increases with exposure time. In addition, it was noted that the strength of corroded specimens cleaned with anti-corrosion agent was consistently low. The minimal strength obtained in the tests was exhibited by joints exposed to ageing for 4 days, and was equal to $0.57 \mathrm{MPa}$. This value corresponded to only $35 \%$ of the maximum strength of the joint in question, which amounted to $1.63 \mathrm{MPa}$ and was observed in the exposure time of 3 months.

As shown, that particular strength values measured in tests are characterised by high variance with regards to time of exposure to ageing of the produced joints. The highest strength was exhibited by joints of substrates pre-treated with Wiko degreaser and subjected to ageing after assembly for 2 months. On the opposite end of the scale were joints pre-treated with Cortanin $\mathrm{F}$ anti-corrosion agent and exposure time of 14 days. In joints whose substrates were subjected to treatment with Wiko degreaser and anti-corrosion agent, the strength demonstrates steady improvement over exposure. For acetone, the highest strength was developed after the joints have been aged for 2 months, beyond which point it begins to decrease, to reach its lowest value after 3 months. The comparative analysis of test results proved that the lowest-strength joint were produced with corroded substrates whose surface had been cleaned by means of anti-corrosion agent, Cortanin F. Furthermore, the lowest scatter of strength values was observed in joints subjected to cleaning with Wiko industrial degreasing agent. The study, therefore, concludes that apart from surface pre-treatment, it is also exposure time that is of high impact on lap shear strength of joints in tensile tests.

\section{Comparative analysis - the bonding surface condition and joint strength}

In order to determine the effect of the state of surface on the strength of joint, the values obtained for corroded and non-corroded specimens depending on exposure time of particular joints were compared. The results of comparison were collated and are shown in Figure 6.

The surface condition of substrates has a considerable influence on the strength of adhesive-bonded joint. The strength observed in joints of non-corroded substrates was characterised by higher values than in the case of corroded steel sheets, regardless of exposure time. This could result from better adhesion of the epoxy to the surface with no corrosion debris loosely bound to the substrate. In sheets covered with rust, the load necessary to detach them from the surface they covered was lower. Therefore, the highest joint strength was obtained when the surface was cleaned with acetone and the joint was exposed to ageing for 2 months. Corroded sheets produced joints whose strength amounted to $4.10 \mathrm{MPa}$, i.e. $89 \%$ of the strength of non-corroded substrates, which was equal to $4.62 \mathrm{MPa}$. Among the analysed values, the average strength was produced by joints after 14 days of exposure. In corroded specimens this amounted to $2.89 \mathrm{MPa}$, which, compared with $3.56 \mathrm{MPa}$ of non-corroded specimens, amounted to $81 \%$ of the latter. The lowest strength values were noted in joints subjected to ageing for 3 months; the strength of $2.4 \mathrm{MPa}$

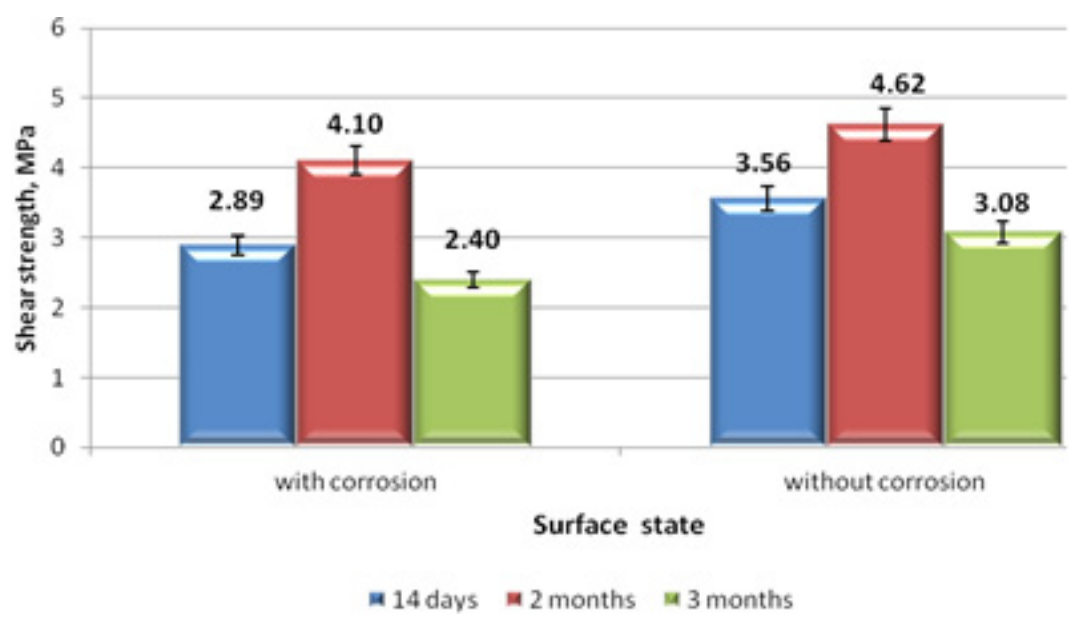

Fig. 6. Joint strength depending on the bonding surface condition 
exhibited by corroded specimens amounted to $78 \%$ of $3.08 \mathrm{MPa}$, which was recorded for specimens with no corrosion products. The determined percentage values indicate that the relationship between the strength of corroded and non-corroded specimens is relatively constant for all ageing exposure time variants. This indicates that it is possible to increase the designed joint strength, even by $0.5 \mathrm{MPa}$ as it was shown in the presented tests, when joined substrates are free from corrosion products.

\section{Statistical analysis of strength test results}

Statistical analysis of results obtained in strength tests consisted in comparing values of adhesive joint strength of S235JR steel sheets, whose surface was subjected to pre-treatment by means of different degreasing agents and exposed to ageing for a specified length of time. The labels for particular series of test specimens are shown in Table 6. The statistical analysis procedure was presented in [21].

Data collected in Table 6 constituted the material for statistical analysis (Table 7) carried out by means of different mathematical models and statistical tests for different variants, which accounted for adhesive-bonded joints produced with specimens subjected to surface - pre-treatment with different cleaning agents. The conducted Snedecor's F-Distribution test showed whether the variances of two populations are equal, whereas the Student's t-test determined the equality of means.
Statistical analysis of the results obtained in lap shear tests shows that in each case the variances are statistically equal. Therefore, for all the analysed adhesive joints of S235JR steel sheet substrates subjected to treatment with different cleaning agents and aged for a particular time there exists no basis for rejecting the hypothesis of equality of variances. This proves that strength test results of such pairs are not statistically significant for two variances at the level of significance equal to $\alpha=0.05$.

The conducted statistical reasoning for equality of means indicates that for all analysed models in variants 1-2, 2-3, 7-9 and 11-12 the hypothesis of equality of means was rejected. In the remaining comparison variants the hypothesis of equality of means was confirmed.

\section{CONCLUSIONS}

The analysis of test results concludes that both the surface condition of substrates and the applied pre-treatment method for the preparation of bonded surfaces as well as exposure time to ageing have a paramount impact on the quality and strength of produced adhesive joints. Lap shear strength of joints in tensile tests showed that the highest strength was exhibited by joints cleaned with acetone and subjected to ageing after bonding for the period of 2 months, in which conditions the strength amounted to 4.10 MPa and surpassed the strength produced

Table 6. Strength values and test variance for particular joint variants

\begin{tabular}{|c|c|c|c|c|c|}
\hline Designation of series & Type of samples & Surface treatment & Ageing time & $\begin{array}{c}\text { Strength, } \\
\mathrm{MPa}\end{array}$ & $\begin{array}{c}\text { Variance, } \\
\mathrm{MPa}\end{array}$ \\
\hline 1 & \multirow{9}{*}{ corroded } & \multirow{3}{*}{ acetone } & 14 days & 2.89 & 0.55 \\
\hline 2 & & & 2 months & 4.10 & 0.63 \\
\hline 3 & & & 3 months & 2.40 & 0.71 \\
\hline 4 & & \multirow{3}{*}{ Wiko } & 14 days & 3.24 & 0.64 \\
\hline 5 & & & 2 months & 3.49 & 0.19 \\
\hline 6 & & & 3 months & 3.69 & 0.39 \\
\hline 7 & & \multirow{3}{*}{ Cortanin F } & 14 days & 0.57 & 0.05 \\
\hline 8 & & & 2 months & 1.29 & 0.08 \\
\hline 9 & & & 3 months & 1.63 & 0.15 \\
\hline 10 & \multirow{3}{*}{ non-corroded } & \multirow{3}{*}{ acetone } & 14 days & 3.56 & 0.30 \\
\hline 11 & & & 2 months & 4.62 & 1.08 \\
\hline 12 & & & 3 months & 3.08 & 0.79 \\
\hline
\end{tabular}


Table 7. Statistical analysis of lap shear strength of adhesive-bonded S235JR steel sheets

\begin{tabular}{|c|c|c|c|c|c|c|}
\hline $\begin{array}{c}\text { Designation of } \\
\text { series }\end{array}$ & $\begin{array}{c}\text { Value of statistic } \\
\mathbf{F}_{\text {obl }}\end{array}$ & $\begin{array}{c}\text { Value of statistic } \\
\mathbf{F}_{\alpha}\end{array}$ & Result & $\begin{array}{c}\text { Value of statistic } \\
\mathbf{T}_{\text {obl }}\end{array}$ & $\begin{array}{c}\text { Value of } \\
\text { statistic } \mathbf{T}_{\alpha}\end{array}$ & Conclusion \\
\hline $1-2$ & 1,11 & 5,192 & $\sigma_{1}{ }^{2}=\sigma_{2}{ }^{2}$ & $-2,07$ & 1,833 & $\mathrm{~m}_{1} \mathrm{~m}_{2}$ \\
\hline $1-3$ & 1,14 & 5,050 & $\sigma_{1}{ }^{2}=\sigma_{3}{ }^{2}$ & 0,87 & 1,812 & $\mathrm{~m}_{1}=\mathrm{m}_{3}$ \\
\hline $2-3$ & 1,02 & 6,256 & $\sigma_{2}{ }^{2}=\sigma_{3}{ }^{2}$ & 2,81 & 1,833 & $\mathrm{~m}_{2} \neq \mathrm{m}_{3}$ \\
\hline $4-5$ & 1,96 & 6,256 & $\sigma_{4}{ }^{2}=\sigma_{5}{ }^{2}$ & $-0,48$ & 1,833 & $\mathrm{~m}_{4}=\mathrm{m}_{5}$ \\
\hline $4-6$ & 1,31 & 6,388 & $\sigma_{4}{ }^{2}=\sigma_{6}{ }^{2}$ & $-0,75$ & 1,860 & $\mathrm{~m}_{4}=\mathrm{m}_{6}$ \\
\hline $5-6$ & 1,50 & 5,192 & $\sigma_{5}{ }^{2}=\sigma_{6}{ }^{2}$ & $-0,42$ & 1,833 & $\mathrm{~m}_{5}=\mathrm{m}_{6}$ \\
\hline $7-8$ & 1,32 & 9,277 & $\sigma_{7}{ }^{2}=\sigma_{8}{ }^{2}$ & $-0,75$ & 1,943 & $\mathrm{~m}_{7}=\mathrm{m}_{8}$ \\
\hline $7-9$ & 1,73 & 9,277 & $\sigma_{7}{ }^{2}=\sigma_{9}{ }^{2}$ & $-2,37$ & 1,943 & $\mathrm{~m}_{7} \neq \mathrm{m}_{9}$ \\
\hline $8-9$ & 1,31 & 9,277 & $\sigma_{8}{ }^{2}=\sigma_{9}{ }^{2}$ & $-0,72$ & 1,943 & $\mathrm{~m}_{8}=\mathrm{m}_{9}$ \\
\hline $10-11$ & 1,82 & 6,256 & $\sigma_{10}{ }^{2}=\sigma_{11}{ }^{2}$ & $-1,75$ & 1,833 & $\mathrm{~m}_{10}=\mathrm{m}_{11}$ \\
\hline $10-12$ & 1,62 & 6,388 & $\sigma_{10}{ }^{2}=\sigma_{12}{ }^{2}$ & 0,80 & 1,860 & $\mathrm{~m}_{10}=\mathrm{m}_{12}$ \\
\hline $11-12$ & 1,12 & 5,192 & $\sigma_{11}{ }^{2}=\sigma_{12}{ }^{2}$ & 2,33 & 1,883 & $\mathrm{~m}_{11} \neq \mathrm{m}_{12}$ \\
\hline
\end{tabular}

Where: $\sigma$ - wariation, $\mathrm{m}$ - mean

by any other joint variant. In addition, a further analysis of test results proved that the lowest strength of joints was produced when bonding corroded steel sheet substrates that were cleaned by means of an anti-corrosion agent, Cortanin F, and ranged from 0.57 to $1.63 \mathrm{MPa}$, regardless of the exposure time.

The comparative analysis showed that the strength of joints increases gradually over time when the adhered surfaces are cleaned with Wiko industrial degreasing agent and anticorrosion agent. Joints pre-treated with acetone, however, obtain the maximum strength after exposure time of 2 months, after which time the strength of the joints in question decreases to exhibit the lowest strength recorded for acetone after 3 months. Furthermore, the lowest scatter of results was observed in joints treated with Wiko industrial degreaser, and ranged between 3.24-3.69 $\mathrm{MPa}$. A further conclusion drawn after analysis of test results is that strength values exhibited by joints with no corrosion debris on the surface of adherends is characteristically higher than joints of corroded substrates, regardless of ageing exposure time. Better adhesion of the epoxy to the surface with no corrosion debris, which is loosely bound to the substrate, could account for the higher joint strength of non-corroded substrates. On the basis of our data we could produce more rigid or more flexible joints, depending on the requirements of a particular application. To recapitulate, there are several factors that contribute to the final strength and quality of adhesive joints, including the condition of surface, surface preparation and ageing exposure time. To produce joints of the best possible quality and strength, an engineer must select the most proper substrate that would be free from corrosion debris, apply suitable surface treatment before bonding and leave the joint for a particular ageing time after the joint is formed. The utmost consideration in selecting the substrate material, preparing the surface for adhesive joining and ageing joints for a proper time period is conducive to obtaining joints of desired properties.

\section{REFERENCES}

1. Brockmann, W., Geiß, P.L., Klingen, J., Schröder, B.: Adhesive Bonding. Materials, Applications and Technology. Germany: Wiley-VCH, Weinheim; 2009.

2. Ebnesajjad, S.: Adhesives Technology Handbook. 2nd edition: William Andrew Publishing; 2008.

3. Adams, R.D., Comyn, J., Wake, W.C.: Structural Adhesive Joints in Engineering Book, 2nd edition. UK: Springer; 1997.

4. da Silva, L.F.M., Carbas, R.J.C., Critchlow, G.W., Figueiredo, M.A.V., Brown, K.: Effect of material, geometry, surface treatment and environment on the shear strength of single lap joints. International Journal of Adhesion and Adhesives, 29, 2009, 621-632.

5. Rudawska, A.: Surface Free Energy and 7075 Aluminium Bonded Joint Strength Following Degreasing Only and Without Any Prior Treatment. Jour- 
nal Adhesion Science and Technology, 26, 2012, 1233-1247.

6. Bouquet, F., Cuntz, J.M., Coddet, C.: Influence of surface treatment on the durability of stainless steel sheets bonded with epoxy. Journal of Adhesion Science and Technology, 6, 1992, 233-242.

7. Rudawska, A.: Selected aspects of the effect of mechanical treatment on surface roughness and adhesive joint strength of steel sheets. International Journal of Adhesion and Adhesives, 50, 2014, 235-243.

8. Rudawska, A., Reszka, M., Warda, T., Miturska, I., Szabelski, J., Stančekova, D., Skoczylas, A.: Milling as a methoof surface pre-treatment of steel for adhesive bonding, Journal of Adhesion Science and Technology, 2016, http://dx.doi.org/10.1080/0 1694243.2016.1191585.

9. Le Bozec, N., C. Compere, C., L'Her, M., Laouenan, A., Costa, D., Marcus, P.: Infuence of stainless steel surface treatment on the oxygen reduction reaction in seawater. Corrosion Science, 43, 2001, 765-786.

10. Maeda, S.: Surface chemistry of galvanized steel sheets relevant to adhesion performance. Progress in Organic Coatings, 28, 1996, 227-238.

11. Elsner, C.I., Cavalcanti, E., Ferraz O., Di Sarli, A.R.: Evaluation of the surface treatment effect on the anticorrosive performance of paint systems on steel. Progress in Organic Coatings, 48, 2003, 50-62.
12. Santágata, D.M., Seré, P.R., Elsner, C.I., Di Sarli, A.R.: Evaluation of the surface treatment effect on the corrosion performance of paint coated carbon steel. Progress in Organic Coatings, 33, 1998, 44-54.

13. Laouar, L., Hamadache, H., Saad, S., Bouchelaghem, A., Mekhilef, S.: Mechanical surface treatment of steel - Optimization parameters of regime. Physics Procedia, 2, 2008, 1213-1221.

14. Seré, P.R., Armas, A.R., Elsners, C.I., Di Sarli, A.R.: The surface condition effect on adhesion and corrosion resistance of carbon steel/chlorinated rubber/artificial sea water systems. Corrosion Science, Vol. 38, No. 6, 1996, 853-866.

15. Surowska B.: Wybrane zagadnienia z korozji i ochrony przed korozją. Politechnika Lubelska, Lublin $2002 \mathrm{r}$.

16. PN-EN 10027-1: 2007: Systemy oznaczania stali Część 1: Znaki stali.

17. http://www.poch.com.pl (accessed on 26.04.2016)

18. http://pl.gluetec-industrieklebstoffe.de (accessed on 26.04.2016)

19. https://strona.organika.com.pl (accessed on 26.04.2016)

20. DIN EN 1465. Adhesives. Determination of tensile lap-shear strength of bonded joints.

21. Krysicki, W., i inni: Rachunek prawdopodobieństwa i statystyka matematyczna w zadaniach. Część II. Statystyka matematyczna. PWN, Warszawa 1997. 